(C) Е.А. Омельченко

\title{
ПРОБЛЕМА АДАПТАЦИИ ДЕТЕЙ ИНОЭТНИЧНЫХ МИГРАНТОВ: НЕГАТИВНЫЙ ДИСКУРС В ИНТЕРНЕТЕ
}

\begin{abstract}
После заседания Совета по межнациональным отношениям при Президенте РФ, состоявшегося 30 марта 2021 года, в сочиальных сетях и блогах появилось множество высказываний и комментариев интернет-пользователей, окрашенных довольно негативно и порой даже агрессивно. Эти высказывания были напрямую связаны с темой обучения и адаптаџии в российских школах детей из семей иноэтничных мигрантов, поднятой на Совете Президентом РФ В.В. Путиным и другими выступающими. Активно проявившийся в интернете, столь негативный дискурс заставляет задуматься о корректности данных о ситуации в сфере межэтнических отношений, которую практически все профильные чиновники характеризуют как достаточно благоприятную. Можно предположить, что, в отличие от «оченки межначиональных отношений в стране», уровень мигрантофобии среди части российского населения продолжает оставаться высоким, особенно когда речь идет о непосредственных ситуациях контактов российских граждан с семьями мигрантов. в образовательных организациях - иколах, колледжах и детских садах - такие контакты становятся неизбежными и регулярными. Автор статьи анализирует отдельные аспекты проявленного негативного этнического и миграционного дискурса и дает некоторые рекомендации по возможному исправлению сложивщейся ситуаџии.
\end{abstract}

Ключевые слова: дети из семей мигрантов, иноэтничные мигранты, миграционные прочессы, межэтническая напряженность, национальная политика, языковая и социально-культурная адаптация, интеграция мигрантов, дискурс в интернете, межэтнические и межрелигиозные конфликты

Для цитирования: Омельченко E.A. Проблема адаптации детей иноэтничных мигрантов: негативный дискурс в интернете // Вестник антропологии, 2021. № 4. C. 269-282.

30 марта 2021 года состоялось заседание Совета по межнациональным отношениям при Президенте РФ, на котором впервые за два десятилетия обсуждалась проблема обучения и адаптации детей из семей иноэтничных мигрантов. в заседании принимали участие лично Президент России В.В. Путин, министр просвещения С.С. Кравцов, руководитель Федерального агентства по делам национальностей И.А. Баринов, руководители профильных комитетов Государственной думы и Сове-

Омельченко Елена Александровна - к.и.н., профессор, зам. директора Института социально-гуманитарного образования, ФГБОУ ВО «Московский педагогический государственный университет» (119991 Москва, ул. Малая Пироговская, 1/1). Эл. почта: ea.omelchenko@mpgu. su, etno1@dol.ru. ORCID: 0000-0002-2019-2586 
та Федерации, ученые и эксперты. На заседании прозвучали данные о том, что, по оценке Министерства просвещения РФ, в российских школах обучаются 140 тысяч детей мигрантов (Стенограмма 2021). Выступающие озвучивали проблемы об отсутствии системы учета детей мигрантов в российских школах и в системе образования, о сложностях в изучении детьми русского языка, о значимой доле обучающихся из семей мигрантов в некоторых классах и школах. Последний сюжет - доля детей иноэтничных мигрантов и беспокойство о том, чтобы не создавались школы, укомплектованные, в основном, учениками из числа детей мигрантов, стал наиболее популярным в СМИ, выпускавших информационные заметки по итогам состоявшегося заседания. Статьи об итогах заседания опубликовали все ведущие российские газеты и интернет-издания (Сведения о наиболее цитируемых газетах взяты: Медиалогия 2021), подавая информацию вполне нейтрально, цитируя выступавших и приводя основные факты. Со ссылками на многие публикации по данной тематике можно познакомиться в разделе «Источники» в конце настоящей статьи.

Совсем другой тональностью отличались публикации отдельных блогеров, которые на протяжении нескольких недель после заседания регулярно появлялись в интернете - например, на популярном канале «Яндекс.Дзен» и других подобных ресурсах. Здесь дискурс уже не всегда был нейтральным: авторы публикаций анализировали ситуацию, исходя из собственного опыта (а у редкого человека не учатся в школе дети или внуки, племянники или, на худой конец, дети знакомых, так что о конкретных ситуациях в российских школах, как правило, всем есть что сказать), появлялись негативно окрашенные высказывания и прямые обвинения власти в непонимании ситуации. Но настоящая «буря» негатива по отношению к теме обучения и адаптации детей мигрантов выплеснулась в комментариях обычных пользователей интернета, читавших либо упомянутые выше «нейтральные» публикации СМИ, либо блоги отдельных авторов. Активно проявившийся в интернете, столь негативный дискурс заставляет задуматься о корректности данных, объявленных в начале 2020 года на заседании президиума Совета по межнациональным отношениям при Президенте РФ, где было сказано, что доля граждан, положительно оценивающих состояние межнациональных отношений в стране, выросла до 81,1 процента (Доля единства 2020). Можно предположить, что, в отличие от «оценки межнациональных отношений в стране», уровень мигрантофобии среди части российского населения продолжает оставаться высоким, особенно когда речь идет о непосредственных ситуациях контактов жителей России с семьями мигрантов, что неизбежно в образовательных организациях - школах, колледжах и детских садах.

В целях подтверждения или опровержения выдвинутой гипотезы автор настоящей статьи предприняла собственное исследование комментариев пользователей интернета и высказываний интернет-блогеров, последовавших за публикацией в СМИ официальных пост-релизов о рассмотрении ситуации с детьми мигрантов в российских школах на Совете по межнациональным отношениям при Президенте РФ 30 марта 2021 года. Анализ проводился за период с 30 марта по 27 мая т.г., всего было проанализировано 465 суждений, высказанных различными интернет-пользователями, из 13 интернет-источников ${ }^{1}$.

При проведении анализа я опиралась на опыт таких исследователей этнической тематики в СМИ, как В.К. Малькова (Малькова 2014), Т.А. Ван Дейк (Дейк 2000),

\footnotetext{
${ }^{1}$ Ссылки на основные источники информации, использованные для анализа, приведены в разделе «Источники» в конце настоящей статьи.
} 
Н.Ю. Зверева (Зверева 2014), А.Г. Пастухов (Пастухов 2018), О.С. Нагорный (Нагорныц̆ 2017) и другие. Из сравнительно недавних зарубежных публикаций мною были проанализированы работы группы европейских исследователей о миграционном дискурсе в европейских медиа (Eberl, Meltzer, Heidenreich, et al. 2018), исследование итальянского ученого Паоло Орру о расистском дискурсе в социальных сетях (Orrù 2014) и научные статьи шведского исследователя Маттиаса Экмана об «интерактивном расизме» и формах его проявления в социальных медиа (Ekman 2018). в контексте моего исследования дискурс рассматривается, согласно Московичи (Moscovici 1981: 181), в качестве одного из главных инструментов, помогающих интерпретировать социальные явления. Соответственно, можно признать, что, как письменные, так и устные тексты оказывают значительное влияние на развитие идентичности и восприятие людьми тех или иных социальных событий, в том числе имеющих отношение к тематике межэтнических отношений.

Многие из проанализированных мною исследований, среди прочего, нацелены на выявление в публикациях разного рода «языка вражды», «образа врага» и прочих высказываний, граничащих с проявлениями экстремистских настроений. Из 465 проанализированных мною высказываний (комментариев читателей после публикаций на официальных сайтах российских газет) только 32 комментария были позитивно окрашены и около 50 были эмоционально нейтральными, остальные можно охарактеризовать как однозначно негативно окрашенные и, по большей части, провоцирующие негативное отношение к этническим мигрантам. Медиапространство российского интернета в этом случае не является исключением из мировой ситуации. Так, в публикации зарубежных исследователей Маджида Хосравиника и Элеоноры Эспозито в анализе этнического дискурса блогов даже используется термин «digital hate» - «цифровая ненависть» (KhosraviNik, Majid and Esposito, Eleonora 2018). A в коллективной публикации американских ученых (Tynes, B., Reynolds, L. and Greenfield P.M. 2004) описываются результаты эксперимента, во время которого в подростковых чатах анализировались высказывания на расовую и этническую темы, и по итогам данного анализа, даже в случае официального наличия в чате взрослого негативный дискурс по вышеуказанной теме составлял 19\%, при видимом же отсутствии взрослых процент негативных мнений вырастал до 59\%. Отмечу, что в рамках моего исследования высказывания, как правило, делались от имени взрослых людей, позиционировавших себя как родителей или потенциальных родителей школьников.

В проанализированных мною письменных комментариях и блогах действительно немало высказываний, выявляющих представление об иноэтничных мигрантах и их детях как о потенциальных врагах нашей страны и нашего общества. Приведу примеры (авторская орфография и стилистика сохранены, имена и «ники» пользователей заменены первыми буквами, для сохранения анонимности):

В., женщина: «Как все не продумано... А так без войны нас уже захватили... Я волнуюсь о своих внуках, им жить в чужом мире» (Комментарий 12021 ).

A., мужчина: «Касается всех, кто защищает всех мигрантов и приезжих с Кавказа людей, чьи дети мешают учиться в российских школах русским детям. И здесь в школах ощущается притеснение детей, которые хорошо учатся... Всех выгнать и принимать по необходимости и нужным специиальностям...» (Комментарий 2 2021). 
Д., мужчина: «Если власть хочет для РФ судьбу Византии, то путь продолжают дальше и не плачут потом, что у них все отберут "эти» приезжие, а это будет. Я вот еще помню, как «эти» изгоняли русских с «их» земли в 90-е. А чего они у нас тут делают, если им стало без русских комфортно жить?» (Комментарий 3 2021).

С., женщина: «Да, речь мигрантов повсюду. Скоро за то, что по-русски говоришь, будут морду бить!!!!!» (Комментарий 4 2021).

Кстати, отсылка к ситуации последнего десятилетия 1990-х годов, когда из-за националистической политики и угроз в сторону русского населения многие жители среднеазиатских республик бывшего СССР должны были покинуть свои дома, встречается достаточно часто (более 60 упоминаний, т.е. примерно 13\% от общего числа проанализированных высказываний), что свидетельствует о сохранении исторической памяти о данном событии, отрицательно влияющей на восприятие мигрантов из Центральной Азии как потомков «тех, кто выгонял» и способствующей формированию негативных стереотипов по отношению к ним. Одним из вариантов решения данной проблемы может стать актуализация исторической памяти о еще более давних событиях - о приеме в городах и селах Средней Азии семей вынужденных мигрантов - преимущественно женщин и детей из Ленинграда, Москвы и других городов европейской части России во время Великой Отечественной войны. Практически это может быть реализовано через информационную кампанию в СМИ и наружной рекламе (билбордах в больших городах), в создании и массированном показе по ТВ и интернету документальных фильмов и тематических передач - жизненных историй на эту тему.

Проявляющееся негативное отношение к взрослым приезжим, к большому сожалению, распространяется и на детей из семей мигрантов, которым многие блогеры и интернет-комментаторы отказывают в праве на получение образования, а зачастую даже в полноценных умственных способностях. Сложно предположить, что в случае рассказа их ребенком - школьником о какой-то сложной учебной или внеучебной ситуации, сложившейся с участием ребенка из семьи мигрантов, такой родитель или другой родственник удержится от комментария с негативной, этнически окрашенной коннотацией, которую потом школьник будет транслировать уже в своей, детской и подростковой среде. Это формирует благоприятную почву для возникновения в школьной среде межэтнических конфликтов или конфликтов между «местными и условно приезжими»:

С., мужчина: «У этих... есть своя родина. Почему из-за них должны страдать наши дети?» (Комментарий 5 2021)

Р., мужчина: «У меня у сына больше половина класса этих...» (Комментарий 6 2021).

Н., мужчина: «Не нужен контроль, нужно всех мигрантов с их необучаемыли... выпнуть за предель России! И проблемь не будет!» (Комментарий 7 2021).

Я.: «Такие маленькие, а уже ЧУРКИ...» (Комментарий 8 2021).

Обращаясь к последнему из приведенных мною комментариев, хотелось бы отметить, что слово «чурка», крайне популярное для высказываний с негативными 
коннотациями на стыке 1990 и 2000-х годов (этому этнофолизму даже было посвящено отдельное исследование (Баринова 2013), сейчас в ряду высказываний встречалось буквально 4-5 раз, что может косвенно свидетельствовать о снижении его популярности, хотя данное предположение необходимо проверять на более широкой выборочной совокупности.

Во многих, проанализированных мною, комментариях интернет-пользователей ставится под сомнение сама возможность культурной адаптации мигрантов, их интеграции в российское общество. Эта тема затрагивается примерно в $15 \%$ подвергшихся изучению высказываний. О способностях к адаптации рядовые интернет-пользователи судят, в основном, по внешним признакам: какую одежду носят мигранты, как общаются между собой: то есть подчеркивается различие во внешности и культуре «своих» и «чужих», проводятся четкие границы, которые невозможно перейти, что по сути является предпосылкой к расистскому дискурсу, по мнению Тён ван Дейка (Дейк 2000: 59).

Х.: «...В родном городе чувствуешь себя неуютно - они везде, крикливые, с толпой детей, завернутые до пят... детей и женщин вернуть на родину, остальным - вахту, поработал и назад» (Комментарий 92021 ).

Д.: «Вот идет семья - пожилой - в длинном халате, девочка в платке, еще подросток. Идут степенно, важно. Много в городе с окладистыли бородами. Я не националист, но... каждый должен жить в своей культуре, со своими традициями ...» (Комментарий 10 2021).

Второй причиной невозможности адаптации является, по мнению интернет-пользователей, исламское вероисповедание мигрантов:

1: «Не научатся они любить вторую родину НИКОГДА, потому что они в основном иновериы, мы и все наше им чуждо было и будет. У них все свое, скоро появятся районы, куда лучше не ходить, как уже есть во многих странах, попытавшихся адаптировать мигрантов» (Комментарий 112021 ).

С., женищна: «Ведут себя очень вольно, как хозяева, пропагандируют ислам, требуют принять их веру, навязывают свои правила и традиции, оскорбляют русских пожилого возраста... и детей многочисленных учат такому отношению... зайдите в выходной день, когда тепло на детскую площадку или на спортивную, черным черно, и русских не пускают на площадки» (Комментарий 12 2021).

Б., мужчина: «Трындец всему РУССКОМУ: культуре, музыке, воспитанию, образованию... Разве русский человек, оказавшись в стране иной веры, устоев, законов и т.д., станет подобным местным аборигенам? Уверена, никогда!!! Тогда зачем мигрантов втюхивать в русское общество. Как были чужие, так навсегда останутся чужаками!!!!!!! Только зло плодят...» (Комментарий 13 2021).

Как мы видим, наличие российских граждан, исповедующих ислам и составляющих большинство населения в некоторых регионах нашей страны, судя по всему, не является для интернет-собеседников аргументом в пользу возможности интеграции мигрантов. Таким образом, необходимо укреплять в коллективном сознании россий- 
ского общества понимание того, что ислам - одна из традиционных религий России, в том числе через просветительскую работу как среди молодежи, так и со взрослым населением. Российские исследователи - антропологи и политологи, занимающиеся данной темой, свидетельствовали, что до недавнего времени мусульманская принадлежность определенной части российских иммигрантов (прежде всего, выходцев из Средней Азии) «не являлась сколько-нибудь значимой темой общественных дискуссий, но, начиная с 2010-х гг., ситуация меняется, и исламская аффилиация среднеазиатских мигрантов становится темой публичных дебатов» (Малахов, Летняков 2018: 266). Превалирование религиозной тематики над этнической, усиление антиисламских стереотипов характерно в последние десятилетия для населения большинства стран Европы, но там исламское население действительно, в основном, имеет миграционное происхождение. Так, Ю.Е. Федорова пишет, что в европейских условиях «любой политический или социальный конфликт с участием мусульман» многие СМИ и отдельные авторы склонны рассматривать «сквозь призму концепции «столкновения цивилизаций» (исламской и европейской), обладающих уникальным культурным «кодом» и принципиально отличным набором ценностных установок» (Федорова 2014). Но в российских условиях подобный нарратив в интернете может стать катализатором весьма негативных тенденций развития общественно-политической ситуации, к возможному возникновению межрелигиозных конфликтов внутри отдельных субъектов РФ. Особенно если подобное негативное отношение будет спроецировано на детей - учеников российских школ:

С., мужчина: «...Какие хиджабы в российских школах??? с ума сошли совсем, и хватит уже строить мечети!!!» (Комментарий 14 2021).

A., мужчина: «...скоро все бабы будут ходить в хиджабах, а мужики в ватных халатах и тюбетейках, и вместо суда будут законы шариата...» (Комментарий 15 2021)

М.: «По сути, нам снова предлагают мультикультурализм. Только под новым названием - приучение детей мигрантов к иколам. в Европе мультикультурализма больше не хотят. Там уже наелись» (Комментарий 16 2021).

Знание Конституции РФ с ее формулировкой «Каждый имеет право на образование» и Конвенции ООН о правах ребенка, ратифицированной Российской Федерацией и закрепляющей право любых детей в России, вне от их гражданской и этнической принадлежности, на получение начального и (по российским законам) основного общего образования, не является характерным для большинства интернет-пользователей. Судить об этом можно хотя бы по тому, что даже в нейтральных и позитивно окрашенных высказываниях - комментариях к новостям о проблематике заседания Совета по межнациональным отношениям при Президенте РФ от 30.03.2021 г., ни эти документы, ни в целом такое понятие, как «права ребенка», вообще не упоминается. Требуется значительная разъяснительная работа с населением по данному поводу - и внимательное отношение к тому, как обществом будут восприняты официально принятые решения и поручения профильным министерствам по итогам вышеупомянутого заседания Совета. По моему мнению, ссылки на российские и международные законы должны в обязательном порядке приводиться и в тех «новостных» публикациях официальных СМИ, и в мнениях экспертов, к 
которым любят обращаться журналисты за комментариями. Пока же непонимание некоторыми жителями России правовых аспектов обучения и адаптации детей из семей мигрантов, а также того, что размер уплачиваемых трудовым мигрантом налогов покрывает, в том числе, и стоимость годичного обучения его детей в школе, приводит, например, к следующим высказываниям:

Р., мужчина: "Дети других культур должнь учиться при посольствах своей страны, не нужно ломать психику и безопасность русских детей» (Комментарий 17 2021).

C., мужчина: «Время открывать русские школьл ... увы!!» (Комментарий 182021 ).

Г., женщина: "Детей мигрантов вообще не должно быть в наших школах, пусть за их образование платят родители, почему они должны учиться на бюджетные деньги...» (Комментарий 19 2021).

Д., мужчина: «...в школах должны русские дети учиться...» (Комментарий $202021)$.

C., женщина: "Спасут православные школьл. Они не пойдут туда, а наши дети смогут спокойно учиться! Иначе как?» (Комментарий 21 2021).

В., мужчина: «Отдельные школь и садики за счет государств - поставщииков мигрантов...» (Комментарий 22 2021).

В проанализированных мною высказываниях интернет-пользователей затрагивается много и других сюжетов, выявляющих негативные стереотипы по отношению к конкретным этническим группам мигрантов - прежде всего, к киргизам, узбекам, таджикам, а также к армянам. Данный нарратив должен стать предметом более детальных исследований, в том числе с привлечением большего числа материалов для контент-анализа и чтобы проследить ситуацию в динамике. Но по итогам предпринятого мною мини-исследования крайне важно упомянуть, что негативный дискурс, проявляющийся в упомянутых интернет-источниках по отношению к проблематике обучения и адаптации детей из семей иноэтничных мигрантов, может отрицательно повлиять на ситуацию в сфере межэтнических и межрелигиозных отношений внутри нашего многонационального государства. Первичный отбор материала для анализа я проводила через наиболее популярные интернет-поисковики Яндекс и Google, вводя в строку поиска словосочетание «обучение детей из семей мигрантов». Собранный мною материал позволяет предположить, что любой интернет-пользователь, прочитавший очередную новость о предпринимаемых государством мерах по вопросам адаптации детей мигрантов и желающий получить дополнительную информацию, натолкнется, в основном, не на грамотные разъяснения экспертов, цитаты из законов и содержательные материалы по данному поводу, а на поток негативных высказываний интернет-пользователей, что может оказать отрицательное влияние и на формирование его отношения к данной теме.

Проблем в сфере обучения и адаптации детей из семей иноэтничных мигрантов действительно довольно много, и я, занимаясь этой темой уже около двадцати лет, неоднократно писала об этом в ряде своих более ранних публикаций (Омельченко 2020; Омельченко 2019). Наличие проблем подтверждают и результаты проек- 
та, реализуемого при моем участии и при поддержке Фонда президентских грантов проекта «Интеграция детей из семей иноэтничных мигрантов средствами образования: методическая и консультативная поддержка школ и детских садов в регионах России» (Информация о проекте 2021). в проекте участвуют 32 образовательные организации из 10 субъектов РФ (Московская, Калужская, Рязанская, Ивановская, Ленинградская, Новосибирская, Свердловская области, город Санкт-Петербург, Ямало-Ненецкий АО и Пермский край); в его рамках с руководителями и представителями администрации, с педагогами и воспитателями образовательных организаций проводились глубинные интервью, а дети из семей иноэтничных мигрантов участвовали в диагностике уровня языковой и социокультурной адаптации к российской образовательной среде.

Участники программы ставят перед собой задачу помочь образовательным организациям со значимой долей обучающихся из семей иноэтничных мигрантов перестроить свою работу таким образом, чтобы проблему адаптации детей мигрантов превратить в ресурс устойчивого развития школы, совместно преодолеть риски отставания и неуспешности, обеспечить положительную динамику образовательных результатов в классах, где учатся дети с миграционной историей. Исследуя школы и детские сады, мы с удивлением убеждались в том, что дети из семей иноэтничных мигрантов, испытывающие трудности во владении русским языком, в социальной и культурной адаптации, это уже не иностранные граждане. Более 400 детей из 700 школьников, участвовавших в диагностике, это дети из семей, которые уже получили российское гражданство, но, несмотря на это, остаются недостаточно интегрированными в российскую среду, плохо владеют русским языком, предпочитая родные языки в домашнем и земляческом общении. в контексте тематики настоящей статьи это означает, что негативный дискурс направлен уже не против иностранных мигрантов, «чужеземцев» и «иноверцев», которые, отработав положенный срок, вернутся в свои страны, а против граждан Российской Федерации «с миграционной историей», имеющих таджикское, киргизское, узбекское, армянское, молдавское и иное этническое происхождение.

Таким образом, можно сделать вывод о том, что наличие в сети разнообразного негативного дискурса по отношению к проблематике адаптации мигрантов и обучения детей мигрантов, в частности, и некоторые аспекты его направленности, подвергнутые мною анализу, свидетельствуют о наличии среди части российского населения достаточно развитых настроений мигрантофобии. По мнению В.К. Мальковой, СМИ и современные медиа (к которым сейчас с полной уверенностью можно отнести и интернет-блоги, и социальные сети) выполняют функцию распространения в массовом сознании не только «новостей и сообщений о некоторых событиях в жизни народов - этносов, но и толерантных или конфликтных этнических ценностей, образов, ориентиров и идей, что оказывает определенное воздействие на формирование общественной атмосферы, массовых взглядов и представлений людей» (Малькова 2014: 101-102). Невозможно запретить людям комментировать те или иные новости (кроме случаев прямого разжигания национальной розни и проявлений экстремизма), но очень важно рекомендовать крупным СМИ сопровождать новостные публикации по вопросам, касающимся межэтнического взаимодействия, достаточно подробными комментариями, ссылками на законы и авторитетными мнениями. Причем ориентировать на такой подход этнические СМИ, как это дела- 
ется, например, на проводимых ежегодно Форумах этнических и региональных медиа (См., например, МДН 2019; в Москве 2020), недостаточно. Прежде всего, нужно практиковать такое подробное комментирование в крупных федеральных СМИ, не ограничивая освещение темы короткими новостными сообщениями. Для темы обучения и адаптации детей из семей иноэтничных мигрантов данный подход мне кажется особенно важным, как средство профилактики возникновения и развития в российском обществе межэтнической и социальной напряженности.

\section{Источники и материалы}

В Москве 2020 - в Москве проходит медиафорум этнических и религиозных СМИ // ТВЦ 30.11.2020. https://www.tvc.ru/news/show/id/198436 (дата обращения: 25.10.2021 г.)

В России 2021 - в России готовят систему оценки образовательных потребностей детей-мигрантов // Парламентская газета. 30.03.2021 г. https://www.pnp.ru/social/v-rossii-gotovyat-sistemu-ocenki-obrazovatelnykh-potrebnostey-detey-migrantov.html (дата обращения: 06.06.2021 г.).

В Совфеде 2021 - в Совфеде предложили создать единую систему учета детей мигрантов // Аргументы и факты. 30.03.2021 г. https://aif.ru/society/v_sovfede_predlozhili_sozdat_edinuyu_sistemu_ucheta_detey_migrantov (дата обращения: 06.06.2021 г.).

Владимир Путин 2021 - Владимир Путин: Число детей мигрантов в школах не должно создавать проблем» // Комсомольская правда. 30.03.2021 г. https://www.kp.ru/ daily/27258/4390242/ (дата обращения: 06.06.2021 г.).

Информация о проекте - Информация о проекте «Интеграция детей из семей иноэтничных мигрантов средствами образования: методическая и консультативная поддержка школ и детских садов в регионах России» // Официальный сайт Московского педагогического государственного университета (МПГУ) www.mpgu.su/integration (дата обращения: 25.04.2021 г.).

Комментарий 12021 - Комментарий читателя к блогу «Раз, два, три, четыре, пять! Будем деток мигрантов в школе мы считать!» // Яндекс Дзен https://zen.yandex.ru/media/ $\mathrm{id} / 5 \mathrm{c} 9 \mathrm{a} 67 \mathrm{c} 1 \mathrm{~d} 2276333 \mathrm{bb} 45 \mathrm{fc} 5 \mathrm{e} / \mathrm{raz}-d v a-t r i-c h e t y r e-p i a t-b u d e m-d e t o k-m i g r a n t o v-v-s h k o l e-$ my-schitat-60638348fa23f523d3f05cc6 (дата обращения: 21.06.2021 г.)

Комментарий 22021 - Комментарий читателя к блогу «После слов президента о школьных классах России, заполненных детьми мигрантов, я поняла, что у нас будет дальше с образованием» // Яндекс Дзен https://zen.yandex.ru/media/northsouth/posle-slov-prezidenta-oshkolnyh-klassah-rossii-zapolnennyh-detmi-migrantov-ia-poniala-chto-u-nas-budet-dalshe-sobrazovaniem-60684934b20786037991ad6b (дата обращения: 19.06.2021 г.)

Комментарий 32021 - Комментарий читателя к публикации «Владимир Путин: Число детей мигрантов в школах не должно создавать проблем» // Комсомольская правда https://www. kp.ru/daily/27258/4390242/\#comments (дата обращения: 21.08.2021 г.)

Комментарий 42021 - Комментарий читателя к публикации «Не любят его учителя. А почему? Потому что он черный?» // Новая газета https:/novayagazeta.ru/articles/2021/05/25/ ne-liubiat-ego-uchitelia-a-pochemu-potomu-chto-on-chernyi (дата обращения: 20.06.2021 г.)

Комментарий 52021 - Комментарий зрителя к видеосюжету «В.В. Путину доложили о проблеме миграционного учёта детей мигрантов в России» // YouTube https://www.youtube. com/watch? $\mathrm{v}=\mathrm{mE6ts} 2 \mathrm{Ppbe} 4$ (дата обращения: 23.06.2021 г.)

Комментарий 62021 - Комментарий читателя к блогу «После слов президента о школьных классах России, заполненных детьми мигрантов, я поняла, что у нас будет дальше с образованием» // Яндекс Дзен https://zen.yandex.ru/media/northsouth/posle-slov-prezidenta-oshkolnyh-klassah-rossii-zapolnennyh-detmi-migrantov-ia-poniala-chto-u-nas-budet-dalshe-sobrazovaniem-60684934b20786037991ad6b (дата обращения: 19.06.2021 г.)

Комментарий 72021 - Комментарий читателя к блогу «Раз, два, три, четыре, пять! Бу- 
дем деток мигрантов в школе мы считать!» // Яндекс Дзен https://zen.yandex.ru/media/ $\mathrm{id} / 5 \mathrm{c} 9 \mathrm{a} 67 \mathrm{c} 1 \mathrm{~d} 2276333 \mathrm{bb} 45 \mathrm{fc} 5 \mathrm{e} /$ raz-dva-tri-chetyre-piat-budem-detok-migrantov-v-shkolemy-schitat-60638348fa23f523d3f05cc6 (дата обращения: 21.06.2021 г.)

Комментарий 82021 - Комментарий читателя к блогу «Школьные гетто - неизбежное будущее. В. Путин высказался о проблеме детей мигрантов в школах» // Яндекс Дзен https:// zen.yandex.ru/media/obrmos_2/shkolnye-getto--neizbejnoe-buduscee-v-putin-vyskazalsiao-probleme-detei-migrantov-v-shkolah-606df9d6a057e8171d5217fa (дата обращения: 18.06.2021 г.)

Комментарий 92021 - Комментарий зрителя к видеосюжету «Дети мигрантов в наших школах» // ОТР-онлайн https://otr-online.ru/programmy/segodnya-v-rossii/deti-migrantov-vnashih-shkolah-49992.html (дата обращения: 05.06.2021г.)

Комментарий 102021 - Комментарий читателя к публикации «Владимир Путин: Число детей мигрантов в школах не должно создавать проблем» // Комсомольская правда https:// www.kp.ru/daily/27258/4390242/\#comments (дата обращения: 21.08.2021 г.)

Комментарий 112021 - Комментарий читателя к публикации «Владимир Путин: Число детей мигрантов в школах не должно создавать проблем» // Комсомольская правда https://www. kp.ru/daily/27258/4390242/\#comments (дата обращения: 21.08.2021 г.)

Комментарий 122021 - Комментарий читателя к блогу «После слов президента о школьных классах России, заполненных детьми мигрантов, я поняла, что у нас будет дальше с образованием» // Яндекс Дзен https://zen.yandex.ru/media/northsouth/posle-slov-prezidentao-shkolnyh-klassah-rossii-zapolnennyh-detmi-migrantov-ia-poniala-chto-u-nas-budet-dalshes-obrazovaniem-60684934b20786037991ad6b (дата обращения: 19.06.2021 г.)

Комментарий 132021 - Комментарий читателя к публикации «Не любят его учителя. А почему? Потому что он черный?» // Новая газета https://novayagazeta.ru/articles/2021/05/25/ ne-liubiat-ego-uchitelia-a-pochemu-potomu-chto-on-chernyi (дата обращения: 20.06.2021 г.)

Комментарий 142021 - Комментарий читателя к блогу «Школьные гетто - неизбежное будущее. В. Путин высказался о проблеме детей мигрантов в школах» // Яндекс Дзен https:// zen.yandex.ru/media/obrmos_2/shkolnye-getto--neizbejnoe-buduscee-v-putin-vyskazalsiao-probleme-detei-migrantov-v-shkolah-606df9d6a057e8171d5217fa (дата обращения: 18.06.2021 г.)

Комментарий 152021 - Комментарий читателя к блогу «Школьные гетто - неизбежное будущее. В. Путин высказался о проблеме детей мигрантов в школах» // Яндекс Дзен https:// zen.yandex.ru/media/obrmos_2/shkolnye-getto--neizbejnoe-buduscee-v-putin-vyskazalsiao-probleme-detei-migrantov-v-shkolah-606df9d6a057e8171d5217fa (дата обращения: 18.06.2021 г.)

Комментарий 162021 - Комментарий читателя к блогу «Раз, два, три, четыре, пять! Будем деток мигрантов в школе мы считать!» // Яндекс Дзен https://zen.yandex.ru/media/ $\mathrm{id} / 5 \mathrm{c} 9 \mathrm{a} 67 \mathrm{c} 1 \mathrm{~d} 2276333 \mathrm{bb} 45 \mathrm{fc} 5 \mathrm{e} / \mathrm{raz}-d v a-t r i-c h e t y r e-p i a t-b u d e m-d e t o k-m i g r a n t o v-v-s h k o l e-$ my-schitat-60638348fa23f523d3f05cc6 (дата обращения: 21.06.2021 г.)

Комментарий 172021 - Комментарий зрителя к видеосюжету «В.В. Путину доложили о проблеме миграционного учёта детей мигрантов в России» // YouTube https://www.youtube. com/watch? $\mathrm{v}=\mathrm{mE6ts} 2 \mathrm{Ppbe} 4$ (дата обращения: 23.06.2021 г.).

Комментарий 182021 - Комментарий читателя к публикации в газете «Ростов-АИФ» // Ростов - АИФ https://rostov.aif.ru/society/persona/chuzhbina_stavit_limit_zachem_ogranichivat_ chislo_detey_migrantov_v_shkole (дата обращения: 08.06.2021 г.)

Комментарий 192021 - Комментарий читателя к публикации «Владимир Путин: Число детей мигрантов в школах не должно создавать проблем» // Комсомольская правда https:// www.kp.ru/daily/27258/4390242/\#comments (дата обращения: 21.08.2021 г.).

Комментарий 202021 - Комментарий читателя к публикации «Владимир Путин: Число детей мигрантов в школах не должно создавать проблем» // Комсомольская правда https:// www.kp.ru/daily/27258/4390242/\#comments (дата обращения: 21.08.2021 г.). 
Комментарий 212021 - Комментарий читателя к публикации «В Совфеде предложили создать единую систему учета детей мигрантов» // Аргументы и факты https://aif.ru/society/v_sovfede_predlozhili_sozdat_edinuyu_sistemu_ucheta_detey_migrantov (дата обращения: 06.06.2021 г.).

Комментарий 222021 - Комментарий читателя к публикации «Путин предложил следить за долей детей мигрантов в школах»// Интернет-портал РБК https://www.rbc.ru/society/30/03/2021/60631c1a9a794795c4323a51 (дата обращения: 06.06.2021 г.).

Малоприятная сфера 2021 - «Малоприятная сфера»: Путин призвал следить за долей детей мигрантов в российских школах» // Новая газета. 30.03.2021 г. https://novayagazeta.ru/ articles/2021/03/30/putin-prizval-sledit-za-dolei-detei-migrantov-v-rossiiskikh-shkolakh (дата обращения: 06.06.2021 г.).

МДН 2019 - Медиафорум этнических и региональных СМИ в рамках проекта ГБУ «МДН» // Московский дом национальностей. Официальный сайт https://mdn.ru/report/mediaforumetnicheskih-i-regionalnyh-smi-v-ramkah-proekta-gbu-mdn-2 (дата обращения: 25.10.2021 г.)

Медиалогия 2021 - ресурс-агрегатор «Медиалогия» https://www.mlg.ru/ratings/media/ federal/8058/ (дата обращения: 05.06.2021 г.).

Путин поручит 2021 - Путин поручит проработать меры для адаптации детей иностранных граждан https://iz.ru/1144347/2021-03-30/putin-poruchit-prorabotat-mery-dlia-adaptatciidetei-inostrannykh-grazhdan (дата обращения: 06.06.2021 г.).

Путин предложил 2021 - Путин предложил следить за долей детей мигрантов в школах // Газета РБК. 30.03.2021 г. https://www.rbc.ru/society/30/03/2021/60631c1a9a794795c4323a51 (дата обращения: 06.06.2021 г.).

Путин призвал 2021 a - Путин призвал следить за долей детей мигрантов в российских школах // Ведомости. 30.03.2021 г. https://www.vedomosti.ru/society/news/2021/03/30/863824-kolichestvo-detei-migrantov (дата обращения: 06.06.2021 г.).

Путин призвал $2021 \mathrm{~b}$ - Путин призвал следить за количеством детей мигрантов в школах» // Московский комсомолец. 30.03.2021 г. https://www.mk.ru/politics/2021/03/30/putin-prizval-sledit-za-kolichestvom-detey-migrantov-v-shkolakh.html (дата обращения: 06.06.2021 г.).

Путин: Доля 2021 - Путин: Доля детей-мигрантов в школах должна позволить адаптировать их к среде в РФ» // Российская газета. 30.03.2021 г. https://rg.ru/2021/03/30/putin-dolia-detej-migrantov-v-shkolah-dolzhna-pozvoliat-adaptirovat-ih-k-srede-v-rf.html (дата обращения: 06.06.2021 г.).

Школа вживания 2021 - Школа вживания. Президент предложил Минпросвещения поровнее рассадить детей-мигрантов // Коммерсант. 31.03.2021 г. https://www.kommersant.ru/ doc/4751905?query=дети\%20мигрантов (дата обращения: 06.06.2021 г.).

Стенограмма 2021 - Стенограмма заседания Совета по межнациональным отношениям при Президенте РФ 30 марта 2021 года http://prezident.org/tekst/stenogramma-vystuplenijaputina-na-zasedanii-soveta-po-mezhnacionalnym-otnoshenijam-30-03-2021.html (дата обращения: 25.04.2021 г.).

\section{Научная литература}

Баринова А. Языковая репрезентация собирательного образа мигранта в российском обществе // Вопросы психолингвистики. 2013. Т. 2. № 18. С. 174-181.

Дейк Т.А. ван. Когнитивные модели этнических ситуаций. Пер. с англ. Г.Е. Крейдлина / Т.А. Ван Дейк. Язык. Познание. Коммуникация. Благовещенск, 2000. С. 161-190.

Дейк Т.А. ван. Язык и идеология: К вопросу о построении теории взаимодействия / Пер. с англ. И.Ф. Ухвановой- Шмыговой // Методология исследований политического дискурса: Актуальные проблемы содержательного анализа общественно-политических текстов / Под общей ред. И.Ф. Ухвановой-Шмыговой. Минск: БГУ, 2000. Вып. 2.

Доля единства. 81,1 процента высоко оценивают межнациональные отношения // Рос- 
сийская газета. 18.02.2021 г. https://rg.ru/2021/02/18/vciom-bolee-80-rossiian-vysokoocenivaiut-mezhnacionalnye-otnosheniia.html (дата обращения: 06.06.2021г.).

Зверева Н.Ю. Дискурсы о мигрантах в современной российской прессе: стратегии борьбы за значение // Новое литературное обозрение. 2014. №4 (128). С. 88-96.

Малахов В., Летняков Д. Ислам в восприятии российским обществом: сравнительно-политический аспект // Государство, религия, церковь в России и за рубежом. 2018. № 2. С. 248-271. DOI: 10.22394/2073-7203-2018-36-2-248-271.

Малькова В.К. Этническая тематика в российском информационном пространстве // Коммуникология. 2014. №5. С. 101-117.

Нагорный О.С. Репрезентация этничностей в русскоязычных социальных медиа // Мониторинг общественного мнения : Экономические и социальные перемены. 2017. № 4. С. 165184. DOI: $10.14515 /$ monitoring.2017.4.11.

Омельченко E.A. Дети из семей мигрантов в российской школе: проблемы адаптации в контексте международных подходов // Вопросы этнополитики. 2020. №1. С. 24-41.

Омельченко E.A. Российская Федерация в контексте миграционных процессов: проблема интеграции иноэтничных мигрантов // Современная научная мысль. 2019. №2. С. 194-201.

Пастухов А.Г. Этнические аспекты идеологизации понятий в миграционном дискурсе / Дискурсология: возможности интерпретации гуманитарного знания. Тезисы докладов участников всероссийской научно-практической конференции с международным участием. Отв. ред. Синельникова Л.Н. 2018. Изд-во Крымского федерального универаситета им. В.И. Вернадского. С. 37-39. https://www.elibrary.ru/item.asp?id=36520287\&selid=36520305 (дата обращения: 06.06.2021 г.). С. 37-39.

Федорова Ю.Е. Ислам в восприятии современного европейского сообщества: стереотипы и реальность // Философская мысль. 2014. № 7. С. 99-125. DOI: 10.7256/23060174.2014.7.13036. https://nbpublish.com/library_read_article.php?id=13036.

Eberl, J.-M., Meltzer, Ch.E., Heidenreich, T., Herrero, B., Theorin, N., Lind, F., Berganza, R., Boomgaarden, H.G., Schemer, C. and Strömbäck, J. 2018. The European media discourse on immigration and its effects: a literature review. Annals of the International Communication Association 42 (3): 207-223, DOI: 10.1080/23808985.2018.1497452.

Ekman M. Anti-refugee Mobilization in Social Media: The Case of Soldiers of Odin. Social Media + Society. January 2018. Doi:10.1177/2056305118764431.

KhosraviNik, M. and Esposito, E. 2018. Online hate, digital discourse and critique: Exploring digitally-mediated discursive practices of gender-based hostility. Lodz Papers in Pragmatics 14 (1): 45-68. https://doi.org/10.1515/lpp-2018-0003.

Moscovici, S. 1981. On social representation. In Social Cognitions: Perspectives on Everyday Understanding, edited by Joseph P. Forgas. London: Academic Press: 181-210.

Orrù, Paolo. 2014. Racist Discourse on social networks: a discourse analysis of Facebook posts in Italy. Rhesis: International Journal of Linguistics, Philology and Literature 51: 113-133.

Tynes, B., Reynolds, L., and Greenfiel, P.M. 2004. Adolescence, race, and ethnicity on the Internet: A comparison of discourse in monitored vs. unmonitored chat rooms. Journal of Applied Developmental Psychology, 25 (6): 667-684. https://doi.org/10.1016/j.appdev.2004.09.003.

Omelchenko, Elena A.

\section{Ethnic Migrants' Children Adaptation: The Negative Internet Discourse}

\section{DOI: $10.33876 / 2311-0546 / 2021-4 / 269-282$}

The Council for Interethnic Relations Working under the President of the Russian Federation (30.03.21) meeting provoked many comments on the Internet with a negative and even aggressive attitude. They reflect on the topic of teaching and adapting children of ethnic migrants'at Russian schools that was discussed at the Council by V. Putin, the President of the 
Russian Federation, and other reporters. The negative discourse manifested so clearly on the Internet made the author question the reliability of the data on the interethnic relations that almost all subject matter officials have characterized as quite favorable. It might be assumed that the degree of migrantophobia in our country, contrary to the "assessment of the interethnic relations in the country," is still relatively high, especially when direct contacts with migrants' families are considered. Such contacts become inevitable at educational organizations schools, colleges, and kindergartens. The article analyzes some aspects of this negative ethnic and migration discourse and gives several recommendations on improving the situation.

Keywords: children from migrants' families, ethnic migrants, migration processes, interethnic tension, national and ethnic policy, linguistic, social and cultural adaptation, integration of migrants, Internet discourse, interethnic and interreligious conflicts

For Citation: Omelchenko, E.A. 2021. Ethnic Migrants' Children Adaptation: The Negative Internet Discourse. Herald of Anthropology (Vestnik Antropologii) 4: 269-282.

Author Info: Omelchenko, Elena A. - Ph.D. in History, Professor, Vice-Director of the Institute of Social and Humanitarian Education, Moscow Pedagogical State University (MPGU) (Moscow, Russia). E-mail: ea.omelchenko@mpgu.su, etno1@dol.ru. ORCID: 0000-0002-2019-2586.

\section{References}

Barinova, A. 2013. Iazykovaia reprezentatsiia sobiratel'nogo obraza migranta v rossiiskom obshchestve [Linguistic Representation of the Collective Image of a Migrant in the Russian Society]. Voprosy psikholingvistiki 2 (18): 174-181.

Deik, T.A. van. 2000. Iazyk i ideologiia: K voprosu o postroenii teorii vzaimodeistviia [Language and Ideology: On Constructing the Theory of Interaction]. In Metodologiia issledovanii politicheskogo diskursa: Aktual'nye problemy soderzhatel'nogo analiza obshchestvennopoliticheskikh tekstov [Methodology of the Research of Political Discourse: Actual Problems of the Content Analysis of Public and Political Texts], edited by I.F. Ukhvanova-Shmygova. Minsk: BGU 2.

Deik, T.A. van. 2000. Kognitivnye modeli etnicheskikh situatsii [Cognitive Models of Ethnic Situations]. In Iazyk. Poznanie. Kommunikatsiia [Language. Cognition. Communication], 161190. Blagoveshchensk.

Dolia edinstva. 81.1 protsenta vysoko otsenivaiut mezhnatsional'nye otnosheniia [Proportion of Unity: 81,1 percent give high score to interethnic relations]. 2021, $18^{\text {th }}$ February. Rossiiskaia gazeta [Russian Newspaper]. https://rg.ru/2021/02/18/vciom-bolee-80-rossiian-vysokoocenivaiut-mezhnacionalnye-otnosheniia.html (date of access: 06.06.2021).

Eberl, J.-M., Meltzer, Ch.E., Heidenreich, T., Herrero, B., Theorin, N., Lind, F., Berganza, R., Boomgaarden, H.G., Schemer, C. and Strömbäck, J. 2018. The European media discourse on immigration and its effects: a literature review. Annals of the International Communication Association 42 (3): 207-223, DOI: 10.1080/23808985.2018.1497452.

Ekman M. 2018. Anti-refugee Mobilization in Social Media: The Case of Soldiers of Odin. Social Media + Society. January. DOI:10.1177/2056305118764431.

Fedorova, Iu.E. 2014. Islam v vospriiatii sovremennogo evropeiskogo soobshchestva: stereotipy i real'nost' [Islam in the Perception of Contemporary European Community: Stereotypes and Reality]. Filosofskaia mysl' [Philosophical Thought] 7: 99-125. DOI: 10.7256/2306-0174.2014.7.13036.

KhosraviNik, M. and Esposito, E. 2018. Online hate, digital discourse and critique: Exploring digitally-mediated discursive practices of gender-based hostility. Lodz Papers in Pragmatics 14 (1): 45-68. https://doi.org/10.1515/lpp-2018-0003 
Malakhov, V., Letniakov, D. 2018. Islam v vospriiatii rossiiskim obshchestvom: sravnitel'nopoliticheskii aspekt [The Islam in the Comprehension of the Russian Society: Contemporary and Political Aspect]. In Gosudarstvo, religiia, tserkov'v Rossii i za rubezhom [State, Religion and Church in Russia and Abroad] 2: 248-271. DOI: 10.22394/2073-7203-2018-36-2-248-271.

Mal'kova, V.K. 2014. Etnicheskaia tematika v rossiiskom informatsionnom prostranstve [Ethnic Subject in the Russian Information Space]. Kommunikologiia [Communicology] 5: 101-117.

Moscovici, Serge. 1981. On social representation. In Social Cognitions: Perspectives on Everyday Understanding, edited by Joseph P. Forgas, 181-210. London: Academic Press.

Nagornyi, O.S. 2017. Reprezentatsiia etnichnostei v russkoiazychnykh sotsial'nykh media [Representation of Ethnicities in the Russian-Language Social Media]. Monitoring obshchestvennogo mneniia: Ekonomicheskie i sotsial'nye peremeny [Monitoring of Public Opinion: Economic and Social Changes] 4: 165-184. DOI: 10.14515/monitoring.2017.4.11.

Omel'chenko, E.A. 2019. Rossiiskaia Federatsiia v kontekste migratsionnykh protsessov: problema integratsii inoetnichnykh migrantov [The Russian Federation in the Context of Migration Processes: the Problem of Integration of Ethnic Migrants]. Sovremennaia nauchnaia mysl' [Contemporary Scientific Thoughts] 2: 194-201.

Omel'chenko, E.A. 2020. Deti iz semei migrantov v rossiiskoi shkole: problemy adaptatsii v kontekste mezhdunarodnykh podkhodov [Children from Migrants' Families at Russian School: Problems of Adaptation in the Context of International Approaches]. Voprosy etnopolitiki [Issues of Ethnopolitics] 1: 24-41.

Orrù, Paolo. 2014. Racist Discourse on social networks: a discourse analysis of Facebook posts in Italy. Rhesis: International Journal of Linguistics, Philology and Literature 51: 113-133.

Pastukhov, A.G. Etnicheskie aspekty ideologizatsii poniatii v migratsionnom diskurse [Ethnic Aspects of Ideologization of Notions in the Migration Discourse]. In Diskursologiia: vozmozhnosti interpretatsii gumanitarnogo znaniia [Discoursology: Opportunities to Interpret the Humanitarian Knowledge], edited by L.N. Sinel'nikova. Izd-vo Krymskogo federal'nogo univerasiteta im. V.I. Vernadskogo: 37-39. https://www.elibrary.ru/item. asp? $\mathrm{id}=36520287 \&$ selid $=36520305$ (date of access: 06.06 .2021 ).

Tynes, B., Reynolds, L., and Greenfiel, P.M. 2004. Adolescence, race, and ethnicity on the Internet: A comparison of discourse in monitored vs. unmonitored chat rooms. Journal of Applied Developmental Psychology, 25 (6): 667-684. https://doi.org/10.1016/j.appdev.2004.09.003.

Zvereva, N. Iu. 2014. Diskursy o migrantakh v sovremennoi rossiiskoi presse: strategii bor'by za znachenie [Discourses on Migrants in the Contemporary Russian Media]. Novoe literaturnoe obozrenie [New Literary Review] 4 (128): 88-96. 